Journal American Society of Mining and Reclamation, 2017 Vol.6, No.2

\title{
CLUSTER PLANTING: EARLY ENHANCEMENT OF STRUCTRUAL DIVERSITY IN A RECLAIMED BOREAL FOREST ${ }^{1}$
}

\author{
Bradley D. Pinno, ${ }^{2}$ Amanda Schoonmaker, Çağdaş Kera Yücel, and Robert Albricht
}

\begin{abstract}
Planting trees is an important step in re-establishing functioning forest ecosystems after industrial land disturbances. Conventional planting practices create forests with evenly spaced trees, at low density, which maximizes individual tree growing space but delays the time until crown closure, potentially for decades. In this study, the first operational cluster planting trial for reclaimed boreal forest, we examined first year tree growth and vegetation competition results of a cluster planting trial in which trembling aspen (Populus tremuloides) trees were planted in clusters of 4 , 10 , or 20 trees with an internal spacing of $0.25 \mathrm{~m}$ along with non-clustered controls. Clustering of aspen seedlings had a measurable impact on the relative proportions of tree and competing vegetation cover with increased tree cover and decreased forb cover in the 10 and 20 seedling clusters compared to the controls. Average seedling height and first year height growth were similar across all cluster treatments but tended to be higher in the clusters, likely due to the suppression of competing vegetation. Operationally, there are still many questions to be answered before this practice can be implemented in a large scale across the landscape. However, based on our initial results, we believe that cluster planting has the potential to become a valuable tool for reclamation practitioners.
\end{abstract}

Keywords: trembling aspen, oil sands reclamation, Alberta, spatial patterns, plant competition

\footnotetext{
${ }^{1}$ Poster presentation at the 2017 Paper presented at the 2017 National Meeting of the American Society of Mining and Reclamation, Morgantown, WV What's Next for Reclamation April 913, 2017. R.I. Barnhisel (Ed.) Published by ASMR, 1305 Weathervane, Champaign, IL 61821.

2 Bradley D. Pinno is a Research Scientist with Natural Resources Canada, Canadian Forest Service, Northern Forestry Centre, Edmonton, Alberta, Canada; Amanda Schoonmaker is an NSERC Industrial Research Chair and Kera Yucel is a Research Officer with Northern Alberta Institute of Technology, Boreal Research Institute, Peace River, Alberta, Canada; Robert Albricht is a Land Stewardship Coordinator with ConocoPhillips Canada, Calgary, Alberta, Canada.
}

Journal American Society of Mining and Reclamation, 2017 Volume 6, Issue 2 pp 37-50

DOI: http://doi.org/10.21000/JASMR17020037 


\section{$\underline{\text { Introduction }}$}

Industrial disturbances related to bitumen extraction in the boreal forest of Alberta, Canada, are very common, and the establishment of trees is a critical step in forest development after industrial disturbance and subsequent land reclamation (Macdonald et al., 2015). It is also important in newly created forests that natural processes such as succession and intraspecific competition among trees occur, resulting in a functioning forest ecosystem. Trembling aspen (Populus tremuloides), a common early successional tree species in the region, typically establishes vegetatively via root suckers after natural disturbances, predominantly wildfire, and anthropogenic disturbances such as timber harvesting (Frey et al., 2003). These naturally established aspen stands can have very high initial stem densities (up to 250,000 stems ha ${ }^{-1}$ ) with heterogeneous clumps of higher and lower tree densities (Das Gupta et al., 2015). However, on completely disturbed and reconstructed reclamation sites, relying on natural suckering is generally not an option without extensive direct placement of upland soil containing aspen roots (Landhäusser et al., 2015). Seedling establishment events may also occur locally on specific reclamation soil types (Pinno and Errington, 2015), but they are still a relatively rare and stochastic event. Therefore, planting trees is a common practice in land reclamation.

The conventional tree planting approach is to establish widely spaced trees (approximately 1,500 stems ha $^{-1}$ ) which is in the range of final stem densities of mature forests in the region. This approach, largely adopted from the forest industry, maximizes individual tree growing space and growth but results in very open stands with little intraspecific competition among trees and a greatly delayed time to reach crown closure, up to 30 years or more in many cases. Reclamation sites can also experience very intense weed pressure from undesirable non-native species (Sloan and Jacobs, 2013; Pinno and Hawkes, 2015). These undesirable species can persist until canopy development reduces light availability to a point that these shade intolerant early successional species fall out of the stand, which can take decades in widely spaced stands. Planting higher

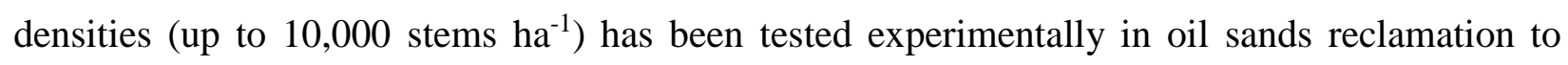
accelerate site capture by the trees (Hankin et al., 2015), but it is unlikely to become a standard operational practice given the higher expense of uniform high-density planting.

A new approach to tree planting in reclamation areas is "cluster planting" in which groups of fast-growing trees, such as aspen, are planted at very high local densities (up to 100,000 stems 
per hectare within the cluster) with no or fewer trees planted in between clusters. This planting approach may be a viable balance of establishing trees in higher density patches without increasing planting expenses, while accelerating the onset of natural processes such as intraspecific competition among trees, controlling undesirable weedy species, and providing habitat for later successional understory plant species. The clumpy spatial pattern may also more closely resemble natural boreal forest regeneration with the unoccupied space between tree clumps allowing for natural revegetation processes to occur. The cluster planting approach may result in a wide variety of microhabitats, from closed canopy forest to more open areas, which may also increase the overall site level biodiversity. Cluster planting has been applied successfully in other forestry settings including oak regeneration in Europe (Saha et al., 2012, 2013), to reduce seedling mortality in mountain forest restoration (Schönenberger, 2001), and bottomland hardwood restoration in the southeast United States (Twedt, 2006), but it has not previously been attempted in the boreal reclamation context. The objective of this study was to establish an operational trial of trembling aspen cluster planting on a reclaimed industrial site in the boreal forest of Alberta and to determine the impact of clustering on the understory plant community and tree growth. We tested a variety of different clustering arrangements, 4, 10, and 20 seedling clusters, along with non-clustered controls. Here we present the first-year results of vegetation composition and competition along with tree growth and survival.

\section{Methods}

This study was based at the ConocoPhillips Surmont SAGD (steam assisted gravity drainage) bitumen recovery facility $\left(56^{\circ} 12^{\prime} \mathrm{N}, 110^{\circ} 57^{\prime} \mathrm{W}, 590 \mathrm{~m} \mathrm{ASL}\right)$ located in northeastern Alberta, Canada, approximately $80 \mathrm{~km}$ south of Fort McMurray. The natural ecosystem in the region is boreal mixed-wood forest with white spruce (Picea glauca) and trembling aspen dominating in the mesic uplands and black spruce (Picea mariana) and tamarack (Larix laricina) dominant in the abundant bog and fen wetlands. The climate is borderline subarctic with average temperatures ranging from $17.1^{\circ} \mathrm{C}$ in July to $-17.4^{\circ} \mathrm{C}$ in January and annual precipitation averaging $420 \mathrm{~mm}$ (Environment Canada Fort McMurray climate normal 1981-2010).

The reclamation study site was located within a 12-ha soil stockpile that had been created during the development of an adjacent industrial facility in 2005. Prior to the establishment of this study, in 2015 the site was treated with herbicide and site-prepared with a bulldozer to eliminate the existing vegetation. The stockpiled soil is intended for future reclamation of the industrially 
disturbed land after 2050. The surface reclamation soil of the study area is derived from upland forest soils and was a mix of the organic forest floor and underlying mineral soil to a depth of approximately $50 \mathrm{~cm}$.

To compare trembling aspen cluster plantings, four cluster treatments were tested with an incluster spacing of $0.25 \mathrm{~m}$ between trees while maintaining an overall density of 2,500 stems ha- ${ }^{-1}$. The treatments were: (1) no clusters, 36 single seedlings planted at a spacing of $2 \mathrm{~m}$ between trees (C0); (2) clusters of 4 aspen seedlings with 3.7 m between clusters (C4); (3) clusters of 10 aspen seedlings with $5.8 \mathrm{~m}$ between clusters (C10); and (4) clusters of 20 aspen seedlings with $8.2 \mathrm{~m}$ between clusters (C20) (Fig. 1). A total of 36 clusters of each size were established. The aspen seedlings were one-year old 615A plug stock from a commercial seedling nursery. At the time of planting in spring 2016, the seedlings had a mean height of $17.6 \mathrm{~cm}$, root collar diameter of $3.1 \mathrm{~mm}$, total stem mass of $0.3 \mathrm{~g}$ dry weight, total root mass of $1.3 \mathrm{~g}$ dry weight, and a root to shoot ratio of 4.8 based on 55 randomly sampled seedlings taken from different seedling boxes prior to planting.

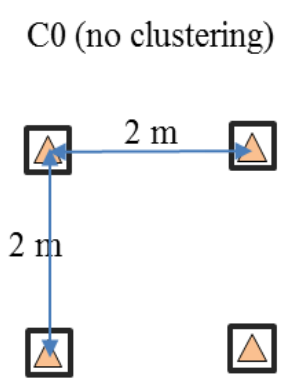

C10 (cluster of 10)

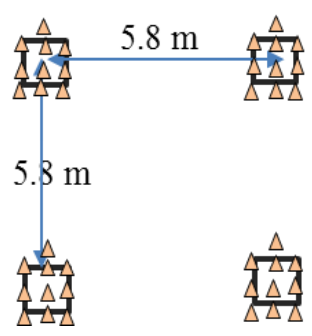

C4 (cluster of 4)

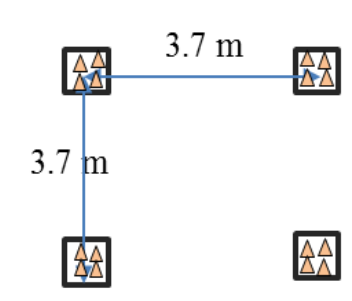

C20 (cluster of 20)

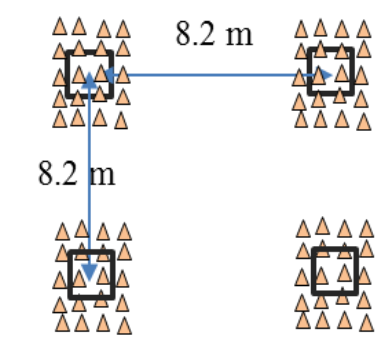

Figure 1. Diagrammatic view of the cluster planting design. Triangles represent planted trembling aspen seedlings while squares represent the central vegetation assessment quadrat. 
In early September 2016 following the cessation of aspen height growth, total height, height increment (current year growth), and survival of all aspen seedlings in each cluster treatment were measured. Vegetation development immediately within and surrounding 20 randomly selected clusters were assessed in each treatment; specifically, average cover of graminoids, forbs, aspen, and other woody plants (non-aspen) from five $0.5 \times 0.5 \mathrm{~m}$ quadrats including the center of each cluster and adjacent quadrats in each cardinal direction.

Data analysis consisted of one-way ANOVA for tree and vegetation data followed by a pairwise comparison test between cluster sizes ( $\mathrm{R}$ statistical software $\mathrm{v}$ 3.2.3). The vegetation cover (aspen, forb, and grass) data set was also explored with ordination using non-metric multidimensional scaling (NMDS), using Bray-Curtis distance matrices and non-metric multivariate analysis of variance to determine the significance in dissimilarity of vegetation groupings across aspen clustering ( $\mathrm{R}$ statistical analysis software v 3.2.3, adonis function of the vegan package and the MASS package). Average aspen first-year-height growth increment and total tree height were also analyzed with linear mixed models fit using REML with the lme function from package nmle (Pinheiro et al., 2009). The relationship between competing vegetation and aspen cover/height was analyzed using regression tree analysis to identify significant thresholds in forb cover that impact aspen development. First year survival of planted aspen was analyzed using a binomial distribution with a generalized linear model.

\section{$\underline{\text { Results }}$}

Clustering of aspen seedlings had a clear visual impact on competing vegetation in the first season after planting with reduced competition in the $\mathrm{C} 10$ and $\mathrm{C} 20$ cluster treatments relative to the $\mathrm{C} 0$ and $\mathrm{C} 4$ clusters (Fig. 2). 

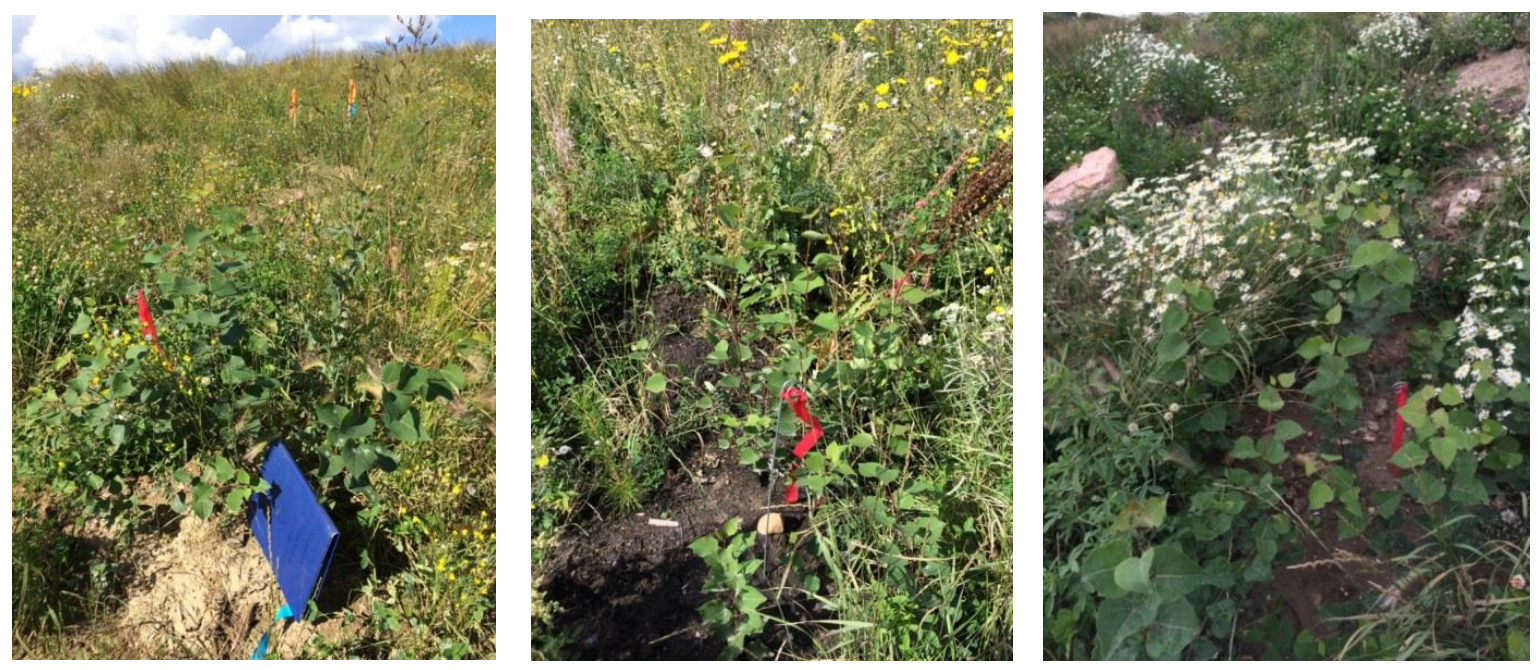

Figure 2. Representative pictures of the tree and vegetation response of each aspen cluster type. Left photo: C4 cluster; center photo, C10 cluster, and right photo: C20 cluster of aspen seedlings. Photos by A. Schoonmaker.

Total vegetation cover, including aspen and competing vegetation, averaged $35 \%$ after the first growing season and was not significantly different among cluster types ( $p=0.179)$ (Fig. 3). However, there were clear trade-offs between vegetation groups with aspen cover increasing from a low of $1.3 \%$ in the $\mathrm{C} 0$ treatment to a high of $9.0 \%$ in $\mathrm{C} 20(\mathrm{p}<0.001)$. In contrast, forb cover decreased from a high of $26 \%$ in the $\mathrm{C} 0$ treatment to a low of $15 \%$ in $\mathrm{C} 20$ ( $\mathrm{p}<0.001)$. This tradeoff between aspen and forb cover appears to have a threshold value of $20 \%$ forb cover with significantly greater $(\mathrm{p}<0.05)$ aspen cover below this threshold (average 5.9\% vs $3.0 \%$ ) across all cluster treatments. This significant threshold for forb cover relative to aspen cover also holds true within each of the cluster treatments with significantly greater aspen cover in the $\mathrm{C} 4, \mathrm{C} 10$, and C20 treatments when there was less than 25, 24 and $18 \%$ forb cover respectively.

Ordination analyses showed that aspen cluster treatments explained $20.9 \%$ of the variation in vegetation composition $(\mathrm{F}=6.69, \mathrm{p}=0.001)$ and that $\mathrm{C} 20$ clusters were clearly different from the $\mathrm{C} 0$ and $\mathrm{C} 4$ clusters with $\mathrm{C} 20$ being associated with higher aspen cover and the $\mathrm{C} 0$ and $\mathrm{C} 4$ being associated with higher forb cover (Fig. 4). 
Journal American Society of Mining and Reclamation, 2017 Vol.6, No.2

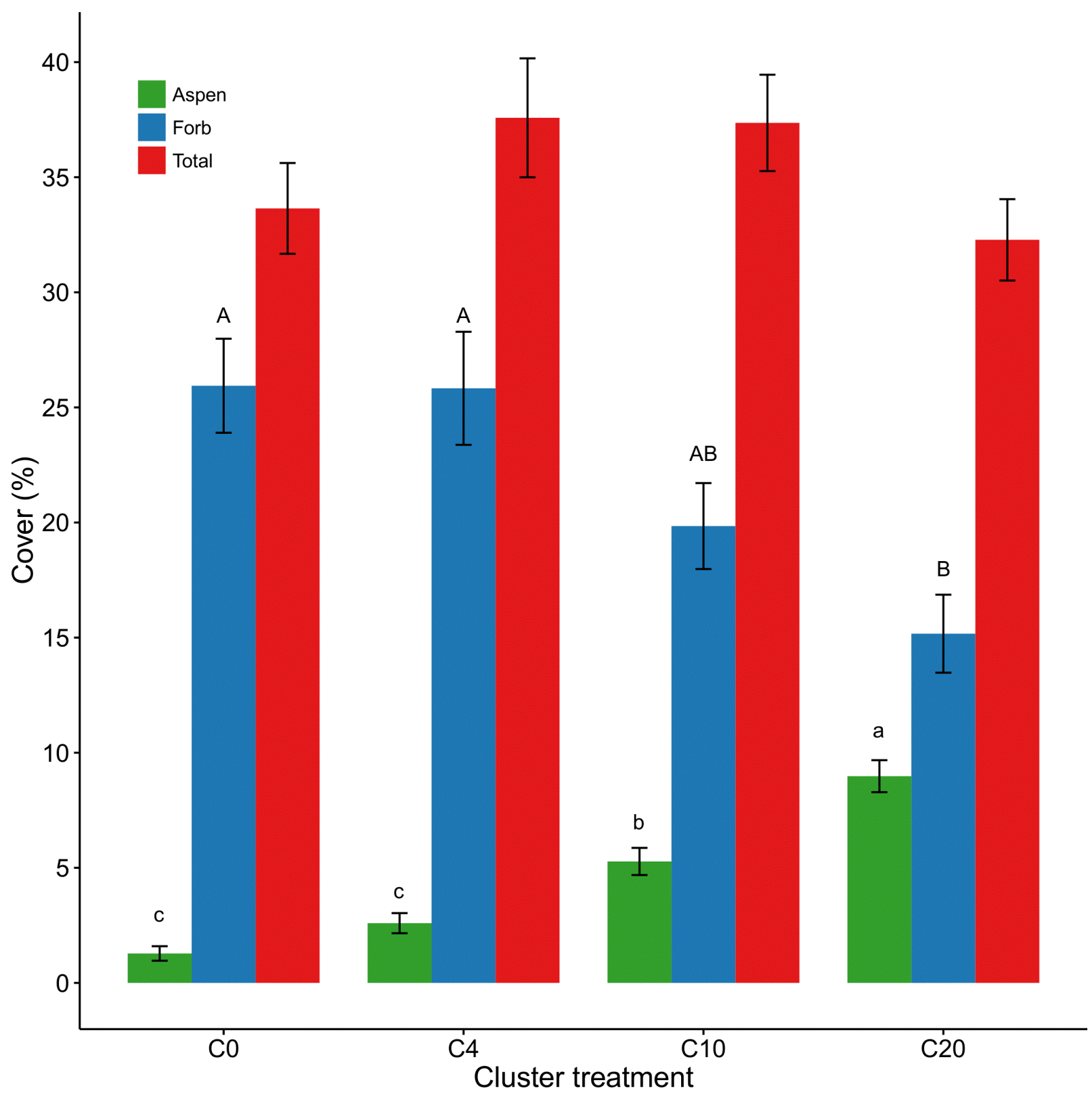

Figure 3: Vegetation cover by cluster treatment for total cover, aspen cover, and forb cover. Values are mean and standard error. Small letters indicate the significant difference $(\mathrm{p}<0.05)$ of aspen cover and capitalized letters indicate the significant difference of forb cover among the cluster treatments. 
Journal American Society of Mining and Reclamation, 2017 Vol.6, No.2

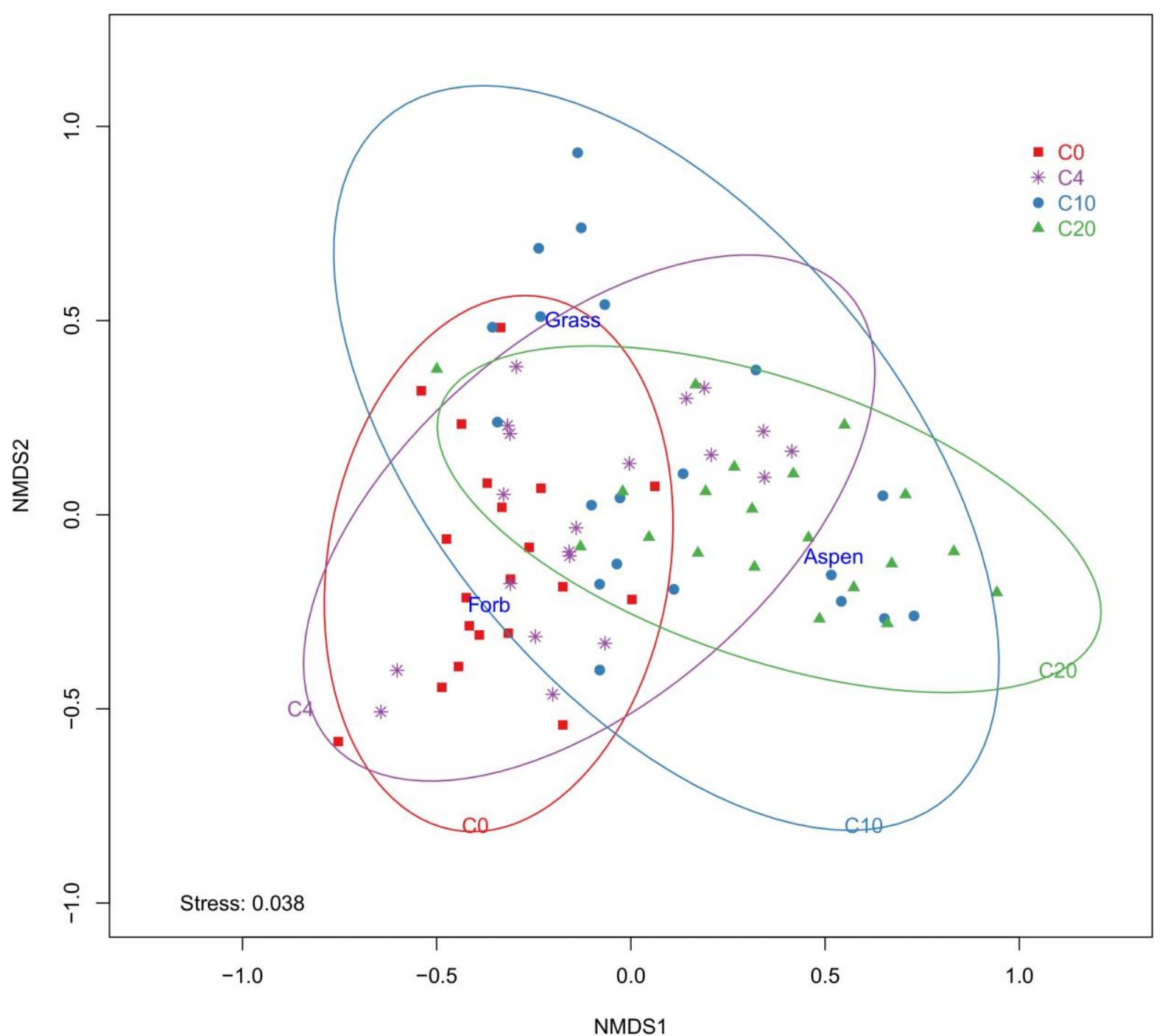

Figure 4. Nonmetric-multidimensional scaling ordination plot based on Bray-Curtis distance matrix of vegetation groupings (aspen, forb, and grass cover) in relation to aspen clustering size $(\mathrm{C} 0, \mathrm{C} 4, \mathrm{C} 10$, and $\mathrm{C} 20)$ from the aspen clusterings. Two-dimensional solutions, stress $=0.038$. The ellipses outline $95 \%$ confidence intervals of sample point position. C0: no clustering, C4: clustering of four aspen seedlings, C10: clustering of 10 aspen seedlings, and C20: clustering of 20 aspen seedlings.

Although not quantified by cover at the species level, the most common forbs across all cluster treatments included both native and non-native species, the most common of which were Chamerion angustifolium, Collomia linearis, and Equisetum sp. (natives) and Crepis tectorum, Sonchus arvensis, and Trifolium hybridum (non-natives). Graminoid cover was not significantly 
different among cluster treatments (average cover $=9 \%, \mathrm{p}=0.293$ ) and the most common species were the native grasses Agropyron trachycaulum and Hordeum jubatum and sedges (Carex sp.).

Average aspen height at the end of the first growing season was not significantly different amongst cluster treatments $(\mathrm{p}=0.577)$ but both height increment as well as total height tended to be higher in clustered treatments (Fig. 5). Regression tree analysis also showed that in the C10 and C20 clusters, aspen height was significantly reduced when competing vegetation cover was greater than 21 and $30 \%$ respectively $(\mathrm{p}<0.05)$. Seedling survival averaged $81 \%$ and was not significantly different among any of the cluster treatments $(\mathrm{p}>0.05)$.

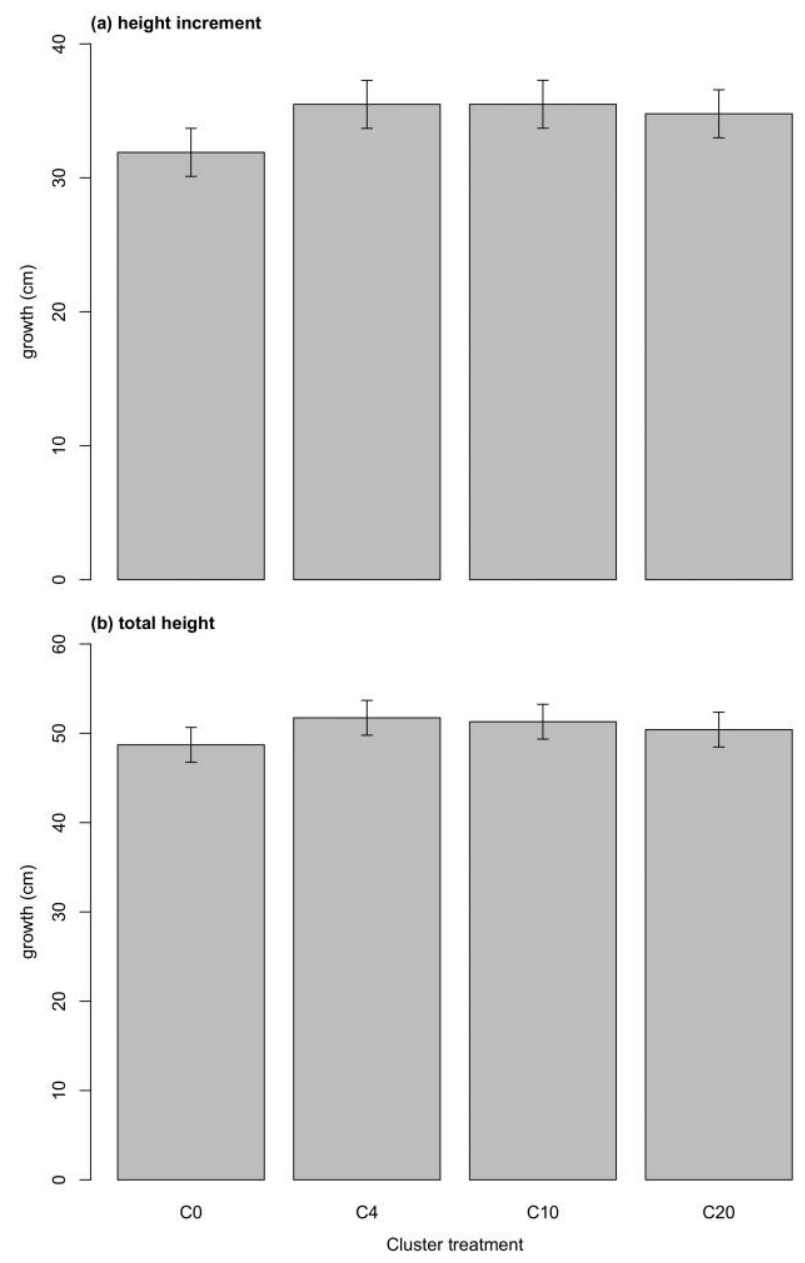

Figure 5. (a) Average first year aspen height growth, and (b) average aspen crop tree height across cluster treatments. Values are average and standard error. 


\section{$\underline{\text { Discussion }}$}

At the local microsite scale, cluster planting has an immediate impact on the relative distribution of vegetation cover with greater aspen cover and lower competing forb cover in the 10 and 20 seedling clusters. Establishing localized high-tree cover patches was an important goal for this project, and after only the first growing season it appears that we have greatly accelerated the time to crown closure within the clusters. Rapid aspen cover development regularly occurs after wildfire as a result of root suckering but planting generally results in a much longer timeline for canopy development (Bartos et al., 1991; Kurzel et al., 2007). The fact that the maximum total vegetation cover was the same for all treatments, but the relative aspen and forb cover varied, demonstrates that it is possible to influence the distribution of total leaf area allocated between plant growth forms to favour desirable tree species.

Though we did not detect a significant growth effect due to clustering, this was only the first growing season and we did observe an average tendency for greater height growth when trees were clustered. This increased growth is an example of facilitation among aspen trees whereby the seedling cluster occupied the physical above-ground space, and likely even below-ground space, thereby restricting forb competition. Aspen is a clonal species used to growing in very close proximity with other ramets in order to integrate resources below ground (Kemperman and Barnes, 1976). Our results provide an example of a similar process occurring above ground with individual genets in the form of plug stock seedlings. Aspen tends to be clumped naturally, either from suckers or seedlings (Kemperman and Barnes, 1976; Quinn and Wu, 2001) and the spatial pattern created by cluster planting resembles the natural patterns with areas of higher and lower densities. Across the site, the result is a variety of different microhabitats that in the longer term will likely favour different species groups. We expect that the clusters will reach canopy closure quickly, resulting in a much darker understory environment that will favour the development of later successional understory species, while the areas in between clusters will favour earlier successional species thereby increasing the overall species diversity across the site.

Trembling aspen is an excellent candidate for this type of cluster planting application since it is early successional, fast growing, adapted to growing at locally high densities when young, and responds to changing resource availability, meaning that it is able to take advantage of reduced competition by growing larger (Greene et al., 1998). Aspen growing on reclamation areas has also 
been shown to have higher maximum growth rates when grown in higher densities (Weber et al., 2017). Other species, such as the later successional conifer white spruce, are not as responsive to changing resources found on reclamation sites and would not be as capable of increasing growth to capture the site quickly. If conifers are the preferred or most appropriate species for a site, an early successional species, such as jack pine (Pinus banksiana), would be another good candidate for cluster planting since it also has similar habitat preferences to aspen and naturally grows in a clumpy distribution when young (Kenkel, 1986).

It is well known that trees and other vegetation compete for limited resources on reclamation sites and we have identified threshold values of around 20-25\% forb cover for increased aspen cover and improved aspen growth. Other studies have shown that increased competing vegetation results in less aspen seedling regeneration (Pinno and Errington, 2015) and reduced tree growth (Pitt et al., 2010). Beyond competition, however, establishing natural vegetation dynamics, such as succession, competition, and facilitation, among understory species is an important part of the land reclamation process (ESRD, 2013). This approach of cluster planting is meant to offer both natural successional pathways in the areas between clusters along with directed succession within the clusters.

In the long term, we believe the clusters will have closed canopy forest understory conditions that will favor certain species while the areas between clusters would have open conditions which would favor different shade-intolerant species. The clusters may also serve as colonization centers for these protection-requiring forest-dependent species as canopy cover develops throughout the reclamation area. This follows on the idea of the 'Islands' approach to reclamation soil placement with patches of high-plant diversity upland topsoil interspersed within a matrix of low-plant diversity lowland reclamation soil (Pinno et al., 2016).

\section{Operational Questions and Recommendations}

One of the goals of this single site operational trial was to begin to quantify the ecological benefits of cluster planting on reclamation areas. However, there are still many questions remaining including the economic benefits and costs of cluster planting compared to conventional planting, i.e., are the potential ecological benefits of cluster planting worth the risks associated with larger unplanted 'gaps' within the reclaimed landscape. Regulatory approvals would also have to be considered, as to whether or not this approach would be acceptable for land managers 
who would potentially have to sacrifice regular stocking for faster crown closure on smaller areas. The optimal cluster patch size, cluster density, internal cluster spacing, and the applicability for other tree species such as jack pine are future areas for testing and evaluation. In this study we have focused on the impact on quadrat level plant community composition, but given the potential increase in diversity of habitats, i.e., open vs closed canopy forest patches, the overall site scale diversity needs to be quantified. Longer-term tree growth also needs to be documented to determine if there is a shift in competition from predominantly inter-specific competition with forbs and other herbaceous plants to intra-specific competition as the trees begin to interact with each other. Overall, we believe that cluster planting of trees on land reclamation sites in the boreal forest of Alberta has the potential to be one of the tools available to reclamation practitioners to help meet the suite of ecological, social, and economic goals for reclaimed land.

\section{Acknowledgements}

We thank Jessica Hudson, Molly Bannister, and Trish Hiley for field and laboratory assistance, Edith Li for reviewing a previous version of this manuscript, and ConocoPhillips and NSERC for funding.

\section{$\underline{\text { Literature Cited }}$}

Bartos, D.L., W.F. Mueggler, and R.B. Campbell. 1991. Regeneration of aspen by suckering on burned sites in Western Wyoming. United States Department of Agriculture, Intermountain Research Station (INT-448). https://doi.org/10.2737/INT-RP-448

Das Gupta, S., M.D. MacKenzie, and S.A. Quideau. 2015. Using spatial ecology to examine above and belowground interactions on a reclaimed aspen stand in northern Alberta. Geoderma, 259260:12-22. https://doi.org/10.1016/i.geoderma.2015.04.004

Environment and sustainable Resource Development (ESRD). 2013. 2010 Reclamation Criteria for Wellsites and Associated Facilities for Forested Lands (Updated July 2013). Edmonton, Alberta. 81p.

Frey, B.R., V.J. Lieffers, S.M. Landhäusser, P.G. Comeau, and K.J. Greenway. 2003. An analysis of sucker regeneration of trembling aspen. Canadian Journal of Forest Research, 33:11691179. https://doi.org/10.1139/x03-053 
Greene, D.F., J.C., Zasada, L. Sirois, D. Kneeshaw, H. Morin, I. Charron, and M.J. Simard. 1998. A review of the regeneration dynamics of North American boreal forest tree species. Canadian Journal of Forest Research, 29: 824-839. https://doi.org/10.1139/x98-112

Hankin, S.L., J. Karst, and M.S. Landhäusser. 2015. Influence of tree species and salvaged soils on the recovery of ectomycorrhizal fungi in upland boreal forest restoration after surface mining. Botany, 93:267-277. https://doi.org/10.1139/cib-2014-0132

Kemperman, J.A. and B.V. Barnes. 1976. Clone size in American aspens. Canadian Journal of Botany, 54: 2603-2607. https://doi.org/10.1139/b76-280

Kenkel, N.C., 1986. Structure and dynamics of jack pine stands near Elk Lake, Ontario: a multivariate approach. Canadian Journal of Botany, 64: 486-497. https://doi.org/10.1139/b86$\underline{063}$

Kurzel, B.P., T.T Veblen, and D. Kulakowski. 2007. A typology of stand structure and dynamics of Quaking aspen in northwestern Colorado. Forest Ecology and Management, 252:176-190. https://doi.org/10.1016/i.foreco.2007.06.027

Landhäusser, S.M., J. Wachowski, and V.J. Lieffers. 2015. Transfer of live aspen root fragments, an effective tool for large-scale boreal forest reclamation. Canadian Journal of Forest Research. 45: 1056-1064, https://doi.org/10.1139/cjfr-2015-0062

Macdonald, S.E., S.M. Landhäusser, J. Skousen, J. Franklin, J. Frouz, S. Hall, D.F. Jacobs, and S. Quideau. 2015. Forest restoration following surface mining disturbance: challenges and solutions. New Forests, 46:703-732. https://doi.org/10.1007/s11056-015-9506-4

Pinheiro, J., D. Bates, S. DebRoy, and D. Sarkar. 2009. Linear and nonlinear mixed effects models, $R$ package version, 3.1-131.

Pinno, B.D. and R.C. Errington. 2015. Maximizing natural trembling aspen seedling establishment on a reclaimed boreal oil sands site. Ecological Restoration, 33:43-50. https://doi.org/10.3368/er.33.1.43

Pinno, B.D. and V.C. Hawkes. 2015. Temporal trends of ecosystem development on different site types in reclaimed boreal forests. Forests, 6:2109-2124. https://doi.org/10.3390/f6062109

Pinno, B.D., L. Sherr, R.C. Errington, and K. Shea. 2016. Islands - soil patches and plant community dynamics on a new oil sands reclamation design. Journal of the American Society of Mining and Reclamation, 5:28-44. https://doi.org/10.21000/JASMR16010028 
Pitt, D.G., P.G. Comeau, W.C. Parker, D. MacIsaac, S. McPherson, M.K. Hoepting, A. Stinson, and M. Mihajlovich. 2010. Early vegetation control for the regeneration of a single-cohort, intimate mixture of white spruce and trembling aspen on upland boreal sites. Canadian Journal of Forest Research, 40: 549-564. https://doi.org/10.1139/X10-012

Quinn R.O. and L. Wu. 2001. Quaking aspen reproduce from seed after wildfire in the mountains of southeastern Arizona. In: Sustaining aspen in western landscapes: symposium proceedings, June 13-15, 2000, Grand Junction, Colorado. Proceedings RMRS-P-18. USDA, Ft. Collins, Colorado, USA: $369-376$.

Saha, S., C. Kuehne, U. Kohnle, P. Brang, A. Ehring, J. Geisel, B. Leder, M. Muth, R. Petersen, J. Peter, W. Ruhm, and J. Bauhus. 2012. Growth and quality of young oaks (Quercus robur and Quercus petraea) grown in cluster plantings in central Europe: A weighted meta-analysis. Forest Ecology and Management, 283:106-118. https://doi.org/10.1016/j.foreco.2012.07.021

Saha, S., C. Kuehne, and J. Bauhus. 2013. Tree species richness and stand productivity in lowdensity cluster plantings with oaks (Quercus robur L. and Q. petraea (Mattuschka) Liebl.). Forests, 4:650-665. https://doi.org/10.3390/f4030650

Schönenberger, W. 2001. Cluster afforestation for creating diverse mountain forest structures $-\mathrm{a}$ review. Forest Ecology and Management, 145:121-128. https://doi.org/10.1016/S0378$\underline{1127(00) 00579-X}$

Sloan, J.L. and D.F. Jacobs. 2013. Fertilization at planting influences seedling growth and vegetative competition on a post-mining boreal reclamation site. New Forests, 44:687-701. https://doi.org/10.1007/s11056-013-9378-4

Twedt, D.J. 2006. Small clusters of fast-growing trees enhance forest structure on restored bottomland sites. Restoration Ecology, 14:316-320. https://doi.org/10.1111/i.1526$\underline{100 X .2006 .00134 . x}$

Weber, J., S. Das Gupta, R. Errington, E. Li, B. Pinno, P.V. Tremblay, J. Hammond, and L. deBortoli. 2017. 2016-17 CFS Reclamation Research Report. Prepared for Canadian Natural Resources Limited. 